\title{
ANALYSIS OF PROGRESS TEST RESULTS IN MEDICAL FACULTY STUDENTS
}

\author{
Ade Pryta R. Simaremare ${ }^{1^{*}}$ \\ ${ }^{1}$ Fakultas Kedokteran Universitas HKBP Nommensen, Medan - INDONESIA \\ Submitted: 02 Sep 2019; Final Revision from Author: 20 Oct 2020; Accepted: 31 Dec 2020
}

\begin{abstract}
Background: Assessment of learning outcomes is an important evaluation material to show how the teaching and learning process has been carried out. It can be obtained from formative and summative assessment, then students are given feedback from these results. One method for formative evaluation is a progress test. During the implementation at the HKBP Nommensen University Faculty of Medicine, there had never been an analysis of the results of the Progress Test activity. This study was conducted for analysing of the results of the Progress Test held in the even semester of the 2018/2019 academic year.
\end{abstract}

Methods: This study used an observational descriptive design with cross sectional method. The sample were all students of the Faculty of Medicine who were actively studying in the even semester of the 2018/2019 Academic Year totaling 215 subjects. Item analysis was done on the questions for basic and clinical medicine category by the level of difficulty and the discrimination index based on students' study period.

Results: Students passing rate that attended the progress test in this study were very low. However, the score achieved by the students increased along with the length of students' study period. Item analysis resulted the difficulty level majority at the medium level, and the discrimination index majority at the poor level for both the basic and clinical medicine science category.

Conclusion: Progress testing can be used as a tool to help curriculum designer see the development of students' knowledge skills both individually and in population.

Keywords: progress test, medical student, formative evaluation, item analysis

\begin{abstract}
ABSTRAK
Latar belakang: Penilaian hasil belajar merupakan bahan evaluasi yang sangat penting untuk menunjukkan bagaimana kualitas proses belajar mengajar yang telah dijalankan. Evaluasi hasil belajar dapat diperoleh dari penilaian formatif dan sumatif, kemudian mahasiswa diberikan umpan balik dari hasil tersebut. Salah satu metode yang dapat dilakukan untuk evaluasi formatif ialah progress test. Fakultas Kedokteran Universitas HKBP Nommensen telah melakukan progress test, namun belum pernah dilakukan analisis terhadap hasil dari kegiatan tersebut. Oleh karena itu penelitian ini dilakukan untuk analisis terhadap hasil progress test yang diadakan pada semester genap tahun ajaran 2018/2019.
\end{abstract}

Metode: Penelitian ini menggunakan disain observasional deskriptif dengan metode Penelitian ini menggunakan disain observasional deskriptif dengan metode cross sectional. Sampel pada penelitian ini

*corresponding author, contact: adesimaremare@uhn.ac.id 
ialah seluruh mahasiswa Fakultas Kedokteran Universitas HKBP Nommensen yang sedang aktif kuliah pada semester genap Tahun Ajaran 2018/2019 yang berjumlah 215 orang. Analisis butir soal dilakukan terhadap soal-soal progress test dengan kategori kedokteran dasar dan klinis berdasarkan tingkat kesukaran dan daya beda soal sesuai angkatan masa studi mahasiswa. Sampel pada penelitian ini ialah seluruh mahasiswa Fakultas Kedokteran Universitas HKBP Nommensen yang sedang aktif kuliah pada semester genap Tahun Ajaran 2018/2019 yang berjumlah 215 orang. Analisis butir soal dilakukan terhadap soal-soal progress test dengan kategori kedokteran dasar dan klinis berdasarkan tingkat kesukaran dan daya beda soal sesuai angkatan masa studi mahasiswa.

Hasil: Angka kelulusan mahasiswa yang mengikuti progress test pada semester genap Tahun Ajaran 2018/2019 sangat rendah. Namun, nilai yang dicapai mahasiswa semakin tinggi sesuai dengan lamanya masa studi mahasiswa. Analisis butir soal menunjukkan hasil tingkat kesukaran mayoritas pada level sedang, dan daya beda mayoritas pada level jelek baik untuk kategori soal ilmu kedokteran dasar dan ilmu kedokteran klinis.

Kesimpulan: Progress test dapat digunakan sebagai alat untuk membantu melihat perkembangan kemampuan pengetahuan mahasiswa baik secara individu maupun di dalam populasi.

Kata kunci: progress test, mahasiswa kedokteran, evaluasi formatif, analisis soal

\section{PRACTICE POINTS}

- This research was conducted on students in one academic year comparing students in 4 batches, based on the basic and clinical medicine science categories which has never been done before.

- An analysis of the items tested in the progress test in this study was conducted to assess the quality of the questions subjectively on the examinees.

- The results of the progress test can be used to help evaluate the learning process in the medical faculty.

\section{PENDAHULUAN}

Pendidikan kedokteran pada dasarnya bertujuan untuk menghasilkan dokter yang profesional melalui proses yang terstandarisasi sesuai kebutuhan pelayanan kesehatan masyarakat. Standar Kompetensi Dokter Indonesia (SKDI) tahun 2012 menjadi salah satu rujukan sebagian besar susunan kurikulum pendidikan dokter di Indonesia yang memuat kompetensi dan kemampuan minimal yang harus dikuasai oleh seorang yang dinyatakan lulus dari suatu fakultas kedokteran. Kompetensi dalam SKDI tersebut dibangun dengan pondasi profesionalisme yang luhur, mawas diri dan pengembangan diri, serta komunikasi efektif, dan ditunjang oleh pilar berupa pengelolaan informasi, landasan ilmiah ilmu kedokteran, keterampilan klinis dan pengelolaan masalah kesehatan yang dikenal dengan 7 (tujuh) area kompetensi. ${ }^{1}$

Kompetensi tersebut akan terpenuhi melalui pengembangan dan integrasi dari tiga domain utama pembelajaran yaitu domain kognitif, psikomotor, dan afektif. Kompetensi tersebut dicapai melalui suatu kurikulum yang harus mampu menyediakan instruksi yang efektif, sumber daya yang memadai, dan asesmen atau penilaian hasil pembelajaran yang tepat. ${ }^{2}$ Kurikulum yang digunakan saat ini di berbagai fakultas kedokteran di Indonesia ialah kurikulum berbasis kompetensi (KBK) dengan metode pembelajaran Problem-Based Learning (PBL), termasuk di Fakultas Kedokteran Universitas HKBP Nommensen. 
Asesmen hasil belajar menjadi bahan evaluasi yang sangat penting untuk menunjukkan bagaimana proses belajar mengajar yang telah dijalankan. Evaluasi hasil belajar dapat diperoleh dari penilaian formatif dan sumatif, kemudian mahasiswa diberikan umpan balik dari hasil tersebut., ${ }^{3,4}$ Namun yang selama ini dilaksanakan di Fakultas Kedokteran Universitas HKBP Nommensen adalah penilaian hasil belajar hanya diperoleh dari evaluasi sumatif sehingga mahasiswa belajar hanya untuk mengejar nilai sumatif. Padahal evaluasi formatif juga diperlukan untuk memberikan gambaran mengenai pemahaman mahasiswa terhadap pengetahuan yang telah mereka peroleh dan memperkuat motivasi mahasiswa untuk menerapkan standar yang lebih tinggi setelah mendapat umpan balik dari evaluasi formatif tersebut. ${ }^{3}$ Penelitian yang dilakukan oleh Manoppo menunjukkan bahwa penilaian formatif pada mahasiswa di FK UNSRAT mempengaruhi hasil penilaian sumatif secara bermakna, dan penilaian formatif yang berkesinambungan akan meningkatkan hasil akhir pada ujian sumatif mahasiswa. ${ }^{4}$

Salah satu metode yang dapat dilakukan untuk evaluasi formatif ialah Progress Test. Ujian ini diberikan pada saat bersamaan dengan interval waktu yang regular (biasanya dua hingga empat kali dalam setahun) kepada mahasiswa pada seluruh angkatan yang aktif pada tahun tersebut. ${ }^{5}$ Ujian tersebut akan mengukur kemampuan mahasiswa dari ranah pengetahuan yang diharapkan tanpa memandang level tahun ajaran yang telah dilewati oleh mahasiswa tersebut. Ujian ini juga memberikan informasi pengukuran perkembangan dan efektivitas dari pembelajaran mahasiswa yang selama ini telah mereka jalani. ${ }^{6}$ Hasilnya, informasi ini dapat digunakan secara konsisten dalam pertimbangan diagnostik, prognostik, dan intervensi perbaikan proses belajar mengajar. ${ }^{5}$

Dalam pelaksanaannya di berbagai fakultas kedokteran, Progress Test telah dimanfaatkan sebagai alat tolak ukur keberhasilan mahasiswa. Penelitian oleh Mirfat menunjukkan adanya peningkatan ratarata ujian dari mahasiswa tahun pertama hingga masa studi tahun keempat yang konsisten dengan tingkat pemahaman materi kuliah setiap angkatannya. ${ }^{4}$
Penelitian yang dilakukan oleh Eliane dkk di fakultas kedokteran di Sao Paulo menyimpulkan bahwa ujian tersebut dapat digunakan sebagai instrumen untuk mengevaluasi capaian pengetahuan, dan sebagai pertimbangan untuk evaluasi lebih lanjut dalam perubahan kurikulum pendidikan secara minor maupun mayor. ${ }^{7}$

Fakultas Kedokteran Universitas HKBP Nommensen telah melakukan Progress Test sekali dalam setiap tahun sejak tahun 2014 terhadap seluruh mahasiswa dari semua angkatan yang sedang aktif kuliah pada tahun ajaran bersangkutan. Selama pelaksanaannya belum pernah dilakukan analisis terhadap hasil dari kegiatan Progress Test tersebut. Penelitian ini bertujuan untuk melakukan analisis terhadap hasil Progress Test yang akan diadakan pada semester genap tahun ajaran 2018/2019.

\section{METODE}

Penelitian ini menggunakan desain observasional analitik dengan metode cross sectional. Yang menjadi sampel pada penelitian ini ialah seluruh mahasiswa Fakultas Kedokteran yang sedang aktif kuliah pada semester genap Tahun Ajaran 2018/2019. Perkiraan mahasiswa aktif yaitu mulai dari angkatan 2018 sebanyak 75 orang, angkatan 2017 sebanyak 41 orang, angkatan 2016 sebanyak 50 orang, hingga angkatan 2015 sebanyak 49 orang, dan total keseluruhan adalah 215 orang. Pengambilan sampel dilakukan dengan teknik total sampling. Prosedur penelitian ini antara lain:

1. Pembuatan soal

Soal ujian diperoleh dari pengampu mata kuliah terkait dari FK yang menjadi anggota AIPKI wilayah 1 yang terdiri atas 18 institusi. Pengumpulan soal dikoordinasi oleh item bank administrator (IBA) masing-masing FK tersebut. Soal dari institusi-institusi tersebut kemudian dikumpulkan dan direview melalui kegiatan pertemuan IBA AIPKI wilayah 1 yang dilakukan pada tanggal 28 Februari - 1 Maret 2019 yang lalu di Padang. Kemudian soal disusun menjadi satu set naskah soal ujian sebanyak 120 soal yang mewakili kompetensi yang terdapat pada SKDI tahun 2012. Susunan konten soal dibuat 
berdasarkan proporsi ujian CBT UKMPPD dan kesepakatan AIPKI wilayah 1. Tipe soal merupakan pilihan berganda, masing-masing terdiri atas clinical vignette, pertanyaan dan 5 pilihan jawaban.

2. Pengaturan lokasi ruang ujian dan pengawas ujian

Ruangan yang dipakai untuk ujian adalah seluruh ruangan yang tersedia di Gedung Murni Sadar sebagai lokasi kegiatan belajar mengajar Fakultas Kedokteran Universitas HKBP Nommensen. Jumlah mahasiswa dalam setiap ruangan diatur sehingga jarak setiap mahasiswa tidak memungkinkan untuk saling mencontek pekerjaan mahasiswa yang lain. Ujian akan diawasi oleh dosen yang bertugas sebagai divisi assessment.

3. Penggandaan soal

Naskah soal yang sudah dikumpulkan digandakan sebanyak 215 eksemplar sesuai dengan jumlah seluruh mahasiswa yang akan mengikuti ujian. Naskah disimpan di tempat yang aman sampai saat ujian dilaksanakan.

4. Pelaksanaan progress test

Progress Test akan dilaksanakan pada awal semester genap Tahun Ajaran 2018/2019 yaitu tanggal 19 Maret 2019 dan diikuti oleh seluruh mahasiswa yang terdaftar sedang aktif kuliah pada semester tersebut.

5. Koreksi hasil progress test

Lembar jawaban mahasiswa dikoreksi dengan menggunakan alat DMR scanner Canon DR-C125 dan dipilah berdasarkan angkatan mahasiswa. Tiap jawaban yang benar diberikan skor 1 (satu), dan tiap jawaban yang kosong maupun salah diberikan skor 0 (nol). Nilai diperoleh dengan membagikan perolehan skor dengan jumlah soal (120 butir) kemudian dikalikan 100. Peserta dinyatakan lulus jika memperoleh nilai $\geq 50$.

6. Analisis hasil progress test

Hasil progress test dianalisis untuk mendapatkan gambaran pencapaian hasil belajar setiap angkatan dalam tahap akademik. Data karakteristik mahasiswa (jenis kelamin, angkatan) dan data hasil progress test ditampilkan dalam tabel distribusi frekuensi. Analisis butir soal berdasarkan tingkat kesukaran, kategori soal (sistem tubuh, kedokteran dasar dan kedokteran klinis) ditampilkan dalam tabel distribusi frekuensi. Analisis bivariat dilakukan untuk melihat hubungan kategori soal (kedokteran dasar dan klinis) dengan tingkat kesukaran dan daya beda soal progress test mahasiswa berdasarkan angkatannya.

\section{HASIL DAN PEMBAHASAN}

\section{Gambaran Progress Test Berdasarkan Nilai dan Kelulusan Mahasiswa}

Progress test pada semester genap Tahun Ajaran 2018/2019 ini telah dilaksanakan pada tanggal 19 Maret 2019 dan diikuti oleh seluruh mahasiswa yang aktif perkuliahan yaitu angkatan 2015 (masa studi tahun ke-4) sebanyak 49 orang, angkatan 2016 (masa studi tahun ke-3) sebanyak 51 orang, angkatan 2017 (masa studi tahun ke-2) sebanyak 40 orang, dan angkatan 2018 (masa studi tahun ke-1) sebanyak 75 orang. Proses ujian berlangsung dengan baik selama lebih kurang 2 jam dengan jumlah soal sebanyak 120 soal yang diperoleh dari hasil review tim Item Bank Administrator (IBA) Asosiasi Institusi Pendidikan Kedokteran Indonesia (AIPKI) Wilayah 1. Butir soal yang diujikan menggunakan format soal sesuai dengan ujian computerized-based test (CBT) Ujian Kompetensi Mahasiswa Program Profesi Dokter (UKMPPD).

Dari gambar 1 dapat diamati nilai terendah, nilai tertinggi, dan nilai rerata dari tiap angkatan yang mengikuti progress test pada semester genap Tahun Ajaran 2018/2019 di Fakultas Kedokteran Universitas HKBP Nommensen. Nilai terendah didapatkan oleh mahasiswa angkatan 2018 yang merupakan angkatan masa studi tahun pertama masuk Fakultas Kedokteran, dan nilai tertinggi diperoleh mahasiswa angkatan 2015 yang merupakan angkatan masa studi tahun ke-4 masuk Fakultas Kedokteran. Hal yang menarik dapat diamati pada perolehan mahasiswa angkatan 2015 dan angkatan 2016 yang menunjukkan skor yang sama yaitu 18 untuk nilai tertinggi dan 57 untuk nilai terendah, walaupun nilai reratanya berbeda karena jumlah mahasiswa pada kedua angkatan ini juga berbeda 


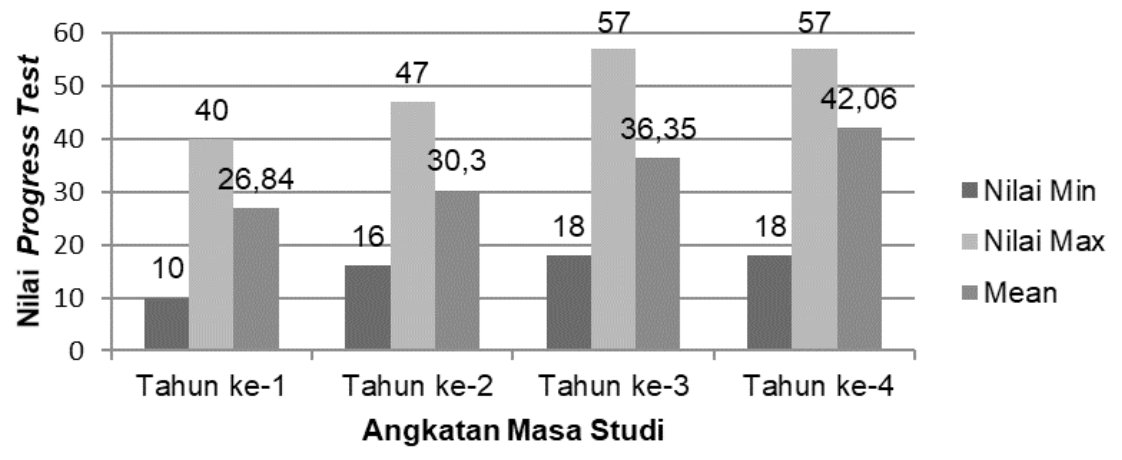

Gambar 1. Grafik sebaran skor progress test pada keempat angkatan

Angka kelulusan mahasiswa tiap angkatan yang mengikuti progress test pada semester genap Tahun Ajaran 2018/2019 dirangkumkan pada tabel 1. Angka kelulusan terendah diperoleh mahasiswa angkatan masa studi tahun ke-1 dan masa studi tahun ke-2 yang menunjukkan bahwa tidak ada mahasiswa yang dapat memperoleh nilai $\geq 50$ pada kedua angkatan tersebut. Angka kelulusan pada mahasiswa angkatan di atasnya yaitu baik angkatan masa studi tahun ke-3 dan angkatan masa studi tahun ke-4 juga cukup rendah yaitu masing-masing $5.9 \%$ dan $10.2 \%$.

Tabel 1. Distribusi Frekuensi Kelulusan Mahasiswa FK UHN Semester Genap TA 2018/2019

\begin{tabular}{lcccccccc} 
& \multicolumn{2}{c}{$\begin{array}{c}\text { Angkatan masa studi } \\
\text { tahun ke-1 }\end{array}$} & $\begin{array}{c}\text { Angkatan masa studi } \\
\text { tahun ke-2 }\end{array}$ & $\begin{array}{c}\text { Angkatan masa studi } \\
\text { tahun ke-3 }\end{array}$ & \multicolumn{2}{c}{$\begin{array}{c}\text { Angkatan masa studi } \\
\text { tahun ke-4 }\end{array}$} \\
\cline { 2 - 9 } & $\mathbf{n}$ & $\%$ & $\mathbf{n}$ & $\%$ & $\mathbf{n}$ & $\%$ & $\mathbf{n}$ & $\%$ \\
Lulus & 0 & 0 & 0 & 0 & 3 & 5.9 & 5 & 10.2 \\
Tidak Lulus & 75 & 100 & 40 & 100 & 48 & 94.1 & 44 & 89.8 \\
Total & 75 & 100 & 40 & 100 & 51 & 100 & 49 & 100 \\
\hline
\end{tabular}

Dari gambar 1 dapat diamati adanya peningkatan skor hasil ujian seiring dengan lamanya masa studi yang ditunjukkan oleh angkatan tahun perkuliahan mahasiswa yang mengikuti ujian tersebut. Mahasiswa angkatan masa studi tahun ke-1 yaitu angkatan 2018 menunjukkan nilai terendah, dan mahasiswa angkatan masa studi tahun ke-4 yaitu angkatan 2015 menunjukkan nilai tertinggi. Demikian pula halnya dengan angka kelulusan yang ditunjukkan oleh tabel 1 yang menunjukkan peningkatan seiring dengan lamanya masa studi mahasiswa. Tidak ada mahasiswa yang memperoleh memperoleh nilai $\geq 50$ pada masa studi masa studi tahun ke-1 dan ke-2 (angkatan 2018 dan 2017) sehingga angka kelulusannya 0 (nol), namun pada mahasiswa masa studi masa studi tahun ke-3 dan ke-4 (angkatan 2016 dan 2015) terdapat mahasiswa yang memperoleh skor $\geq 50$ walaupun tidak signifikan yaitu 3 orang dan 5 orang. Hasil yang sama diperoleh oleh penelitian Mirfat $^{4}$ yang menunjukkan bahwa semakin lama masa studi mahasiswa dalam mengikuti proses belajar maka nilai progress test yang dicapai akan semakin baik. Pada penelitian yang dilakukan terhadap mahasiswa Fakultas Kedokteran di YARSI ini mahasiswa pada angkatan pertama mendapatkan rerata nilai terendah, dan mahasiswa angkatan keempat mendapatkan rerata nilai yang tertinggi.

Progress test menguji perkembangan pengetahuan mahasiswa dalam kurikulum, suatu bukti yang menunjukkan perkembangan ini merupakan sumber yang kuat dari konstruksi bukti validitas. Perkembangan pengetahuan yang terus-menerus ini direfleksikan melalui peningkatan skor rerata dari hasil ujian seiring masa studi mahasiswa dan adanya perbedaan dalam skor rerata tersebut di antara masingmasing masa studi. ${ }^{8}$ Penelitian yang dilakukan oleh Reed et $\mathrm{al}^{9}$ menunjukkan bahwa performa mahasiswa 
meningkat secara substansial seiring dengan tahun pendidikannya, baik dalam ujian rekognisi pola diagnostik maupun interpretasi data klinis. Progress test dapat memberikan informasi mengenai berbagai aspek dari mahasiswa dan evaluasi kurikulum, termasuk perbandingan teman sebaya antaruniversitas, perbandingan di antara mahasiswa untuk mengidentifikasi mahasiswa yang akan remedial, sebagai asesmen formatif dalam bagian dari seluruh rencana asesmen, untuk menilai progresi dalam kurikulum, dan sebagai tambahan dalam evaluasi program pendidikan. ${ }^{2,10,11}$ Pada pelaksanaannya, progress test ini dilakukan bersamaan dengan FK lain dari 18 institusi dalam cakupan AIPKI Wilayah 1. Dengan demikian akan dapat dibandingkan performa mahasiswa dari institusi lain yang juga melakukan progress test tersebut. Mahasiswa yang memperoleh nilai yang baik dalam keseharian masa perkuliahannya juga menunjukkan nilai yang lebih baik dibandingkan mahasiswa yang lain dalam angkatannya masingmasing. Implementasi dari progress test yang dilaksanakan di FK Universitas HKBP Nommensen selama ini pada kurikulum adalah sebagai masukan dalam perjalanan revisi kurikulum baik secara minor maupun mayor. Secara mayor salah satunya dalam hal urutan blok yang dilaksanakan selama masa kuliah, dan secara minor dalam metode penyampaian materi perkuliahan oleh dosen pengampu sehingga lebih mudah dipahami oleh mahasiswa.

\section{Analisis butir soal yang diujikan terhadap mahasiswa}

Soal-soal yang diujikan pada progress test tersebut merupakan soal yang diperoleh dari hasil kegiatan review para Item Bank Administrator (IBA) Asosiasi Institusi Pendidikan Kedokteran Indonesia (AIPKI) Wilayah 1. Tim ini berasal dari berbagai Fakultas Kedokteran yang mengutus dosen pengampu mata kuliah yang akan diujikan dalam progress test tersebut. Kategori soal dibagi atas berbagai sistem tubuh dan tahapan ilmu kedokteran dan keseluruhan soal berjumlah 120 butir. Distribusi frekuensi kategori soal ditunjukkan oleh tabel 2. sedangkan tabel 3 merangkumkan tingkat kesukaran butir soal berdasarkan angkatan yang berbeda-beda.

Tabel 2. Distribusi Frekuensi Kategori Soal Progress Test Mahasiswa FK UHN Semester Genap T.A 2018/2019

\begin{tabular}{|c|c|c|c|}
\hline \multicolumn{2}{|c|}{ Kategori Soal } & \multirow{2}{*}{$\frac{\mathbf{n}}{8}$} & \multirow{2}{*}{$\begin{array}{c}\% \\
6.7\end{array}$} \\
\hline \multirow{13}{*}{ Berdasarkan Sistem Tubuh } & Endokrin & & \\
\hline & Gastrointestinal, Hepatobilier, dan Pankreas & 9 & 7.5 \\
\hline & Ginjal \& Saluran Kemih & 8 & 6.7 \\
\hline & Hematoimunologi & 8 & 6.7 \\
\hline & Indra & 9 & 7.5 \\
\hline & Integumen & 9 & 7.5 \\
\hline & Kardiovaskular & 8 & 6.7 \\
\hline & Muskuloskeletal & 8 & 6.7 \\
\hline & Non-sistem & 18 & 15.0 \\
\hline & Psikiatri & 9 & 7.5 \\
\hline & Reproduksi & 9 & 7.5 \\
\hline & Respirasi & 8 & 6.7 \\
\hline & Saraf & 9 & 7.5 \\
\hline Total & & 120 & 100 \\
\hline \multirow{2}{*}{ Berdasarkan Tahap Ilmu Kedokteran } & Dasar & 35 & 29.2 \\
\hline & Klinis & 85 & 70.8 \\
\hline Total & & 120 & 100 \\
\hline
\end{tabular}


Dari tabel 2 dapat dilihat bahwa soal yang diujikan berasal dari 12 sistem dan 1 bagian merupakan nonsistem. Komposisi soal dibuat merata di tiap sistemnya sehingga dapat mencakup keseluruhan mata ajaran berdasarkan sistem tubuh yang diajarkan pada masa pendidikan kedokteran dari tahun pertama hingga menjelang akhir. Soal juga dapat dikategorikan berdasarkan tahap ilmu kedokteran yaitu ilmu dasar dan ilmu klinis. Dalam paket soal ini. butir soal ilmu kedokteran klinis dibuat dalam komposisi yang lebih besar daripada ilmu kedokteran dasar yaitu 85 soal dibandingkan dengan 35 soal.

Salah satu tujuan utama dari progress test adalah melakukan evaluasi ketercapaian pembelajaran longitudinal, atau aspek developmental dari kurikulum, dalam hal ini sepanjang masa studi dalam pendidikannya di fakultas kedokteran. Oleh karena itu, pengetahuan yang diujikan meliputi pengetahuan dari tiap sistem tubuh, yang terdiri atas ilmu kedokteran dasar dan kedokteran klinis. Ujian ini harus dapat menilai pengetahuan kesehatan terapan dari tiap tahapan kurikulum, selain itu harus dapat mendorong pembelajaran yang berorientasi pada makna dan juga membantu meningkatkan retensi pengetahuan jangka panjang, dan mengurangi strategi pembelajaran superfisial. Pertanyaan-pertanyaan dalam progress test ini diambil dari bank soal yang meliputi area mayor dari pengetahuan dasar, klinis, ilmu perilaku, dan kesehatan masyarakat, yang diharapkan dari seorang dokter kelak. ${ }^{12-14}$

Analisis butir soal merupakan suatu proses mengumpulkan, meringkas, dan menggunakan informasi dari respon mahasiswa untuk menilai kualitas dari butir soal. Dua parameter dalam analisis ini adalah tingkat kesukaran dan daya beda yang akan membantu dalam evaluasi standar dari pertanyaan bentuk pilihan berganda yang digunakan dalam ujian. Tingkat kesukaran menunjukkan persentase jumlah jawaban benar terhadap butir soal atau peluang untuk menjawab benar suatu soal pada tingkat kemampuan tertentu. Rumus tingkat kesukaran ini adalah jumlah mahasiswa yang menjawab benar pada kelompok nilai tinggi ditambah jumlah mahasiswa yang menjawab benar pada kelompok nilai rendah dibagi dengan jumlah seluruh mahasiswa. Indeks tingkat kesukaran dinyatakan dalam bentuk rasio yang nilainya berkisar antara 0,00 - 1,00 yaitu kurang dari 0,3 untuk soal sukar, 0,3 - 0,7 untuk soal sedang, dan 0,7-1 untuk soal mudah. Sedangkan daya beda soal merupakan ukuran perbandingan antara persentase jumlah mahasiswa kelompok tinggi dengan jumlah mahasiswa kelompok rendah yang dapat menjawab soal dengan benar. ${ }^{15,16}$

Faktor mahasiswa meliputi hal-hal yang bersifat individual, seperti pembelajaran mahasiswa saat preklinik, minat mahasiswa, waktu belajar, motivasi belajar, dan pengetahuan mahasiswa mengenai ilmu dasar kedokteran. Berdasarkan penelitian, mahasiswa dengan prior knowledge dan motivasi yang adekuat akan mendorong proses pembelajaran menjadi lebih baik dan pemahaman materi akan menjadi lebih mudah. ${ }^{11}$

Tabel 3 menunjukkan analisis butir soal berdasarkan tingkat kesukaran dan daya beda. Tingkat kesukaran soal dibagi atas mudah, sedang dan sukar sedangkan daya beda soal dibagi atas jelek, lemah, sedang, dan baik. Pada mahasiswa angkatan masa studi tahun ke-1 dan masa studi tahun ke-2 soal yang diujikan berada pada tingkat kesukaran yang sukar yaitu masingmasing sebesar $100 \%$, sedangkan pada mahasiswa angkatan masa studi tahun ke-3 dan masa studi tahun ke-4 tingkat kesukaran mayoritas sedang yaitu $60.8 \%$ dan 57.5\%. Untuk daya beda soal pada mahasiswa angkatan masa studi tahun ke-1 dan masa studi tahun ke-2 tidak dapat ditentukan oleh karena tidak ada mahasiswa yang lulus pada kedua angkatan tersebut, sehingga daya beda yang dibandingkan pada mahasiswa kelompok tinggi (mahasiswa yang lulus) dan mahasiswa kelompok rendah (mahasiswa yang tidak lulus) tidak dapat dihitung. Pada mahasiswa angkatan masa studi tahun ke-3 dan masa studi tahun ke-4 daya beda soal mayoritas pada kategori jelek yaitu masingmasing $62.5 \%$ dan $49.2 \%$. 
Tabel 3. Distribusi Frekuensi Tingkat Kesukaran dan Daya Beda Soal Progress Test Mahasiswa FK UHN Semester Genap T.A 2018/2019

\begin{tabular}{|c|c|c|c|c|c|c|c|c|c|}
\hline \multicolumn{2}{|c|}{ Analisis Butir Soal } & \multicolumn{2}{|c|}{$\begin{array}{c}\text { Angkatan masa studi } \\
\text { tahun ke-1 }\end{array}$} & \multicolumn{2}{|c|}{$\begin{array}{c}\text { Angkatan masa studi } \\
\text { tahun ke-2 } \\
\end{array}$} & \multicolumn{2}{|c|}{$\begin{array}{c}\text { Angkatan masa studi } \\
\text { tahun ke-3 }\end{array}$} & \multicolumn{2}{|c|}{$\begin{array}{l}\text { Angkatan masa } \\
\text { studi tahun ke-4 }\end{array}$} \\
\hline & & $\mathrm{n}$ & $\%$ & $\mathrm{n}$ & $\%$ & $\mathrm{n}$ & $\%$ & $\mathrm{n}$ & $\%$ \\
\hline \multirow{3}{*}{$\begin{array}{l}\text { Tingkat } \\
\text { Kesukaran }\end{array}$} & Mudah & 0 & 0 & 0 & 0 & 6 & 5 & 16 & 13.3 \\
\hline & Sedang & 0 & 0 & 0 & 0 & 73 & 60.8 & 69 & 57.5 \\
\hline & Sukar & 120 & 100 & 120 & 100 & 41 & 34.2 & 35 & 29.2 \\
\hline \multirow{4}{*}{ Daya Beda } & Buruk & - & - & - & - & 75 & 62.5 & 59 & 49.2 \\
\hline & Lemah & - & - & - & - & 16 & 13.3 & 16 & 13.3 \\
\hline & Sedang & - & - & - & - & 15 & 12.5 & 9 & \multirow{2}{*}{$\begin{array}{l}7.5 \\
30.0\end{array}$} \\
\hline & Baik & - & - & - & - & 14 & 11.7 & 36 & \\
\hline
\end{tabular}

Dalam pelaksanaan progress test perlu dilakukan evaluasi terhadap butir soal yang diujikan kepada mahasiswa tersebut. Analisis butir soal menguji respon mahasiswa terhadap butir soal (terutama soal pilihan berganda) untuk menilai kualitas dari pertanyaan tersebut dan ujian secara keseluruhan untuk meningkatkan atau memperbaiki butir soal maupun ujian tersebut. Pertanyaan yang baik dapat menilai baik domain kognitif, afektif, dan psikomotor dan lebih disukai dibandingkan metode yang lain oleh karena objektifitas dalam penilaiannya, keterbandingannya dengan keadaan yang berbedabeda, cakupan subjek yang luas, dan minimalisir bias dari asesor. Analisis butir soal di antaranya adalah berdasarkan indeks tingkat kesulitan soal dan daya beda (indeks diskriminasi). ${ }^{15,17}$

Dalam penelitian ini, tingkat kesukaran dan daya beda soal dibandingkan pada semua angkatan baik angkatan masa studi tahun pertama hingga masa studi tahun ke-4 (angkatan 2018, 2017, 2016, dan 2015). Di FK Universitas HKBP Nommensen, mahasiswa angkatan masa studi ke-1 dan ke-2 belum banyak terpapar dengan bentuk soal yang menggunakan clinical vignette oleh karena dalam kurikulumnya diberikan mata kuliah dasar umum dan hanya sebagian kecil menyangkut masalah klinis. Mata kuliah klinis mulai diperkenalkan pada pertengahan masa studi tahun ke-1 namun belum mendominasi. Dalam clinical vignette, mahasiswa perlu memikirkan clinical reasoning dari kasus yang dipaparkan, tidak hanya sekedar hapalan. Hal inilah yang masih belum terbentuk secara mandiri pada mahasiswa masamasa studi awal. Itulah sebabnya pada mahasiswamahasiswa ini (angkatan 2018 dan 2017) semua soal berada dalam level sukar. Hal ini menyebabkan tidak ada mahasiswa yang lulus pada mahasiswa kedua angkatan tersebut, seluruh mahasiswa tersebut tidak mampu memperoleh skor $\geq 50$ dalam ujian tersebut. Pada mahasiswa masa studi masa studi tahun ke-3 (angkatan 2016) dan ke-4 (2015), tingkat kesukaran soal berada pada level sedang.

Tingkat kesukaran soal merupakan indeks yang menyatakan tingkat kesulitan tiap pertanyaan. Skor tingkat kesukaran yang dapat diterima adalah 0,30,7 yaitu pada level sedang. ${ }^{18}$ Tingkat kesukaran soal level sedang menunjukkan bahwa materi yang ditanyakan sudah diajarkan atau tuntas pembelajarannya, sehingga mahasiswa sudah dapat menguasai kompetensi minimum yang harus dicapai. ${ }^{16,18}$ Tingkat kesukaran soal menunjukkan persentase mahasiswa yang dapat menjawab soal dengan benar, diharapkan sebesar $30-70 \%$. Soal yang sukar harus direview mengenai kemungkinan bahasa yang membingungkan, area kontroversi, atau kunci jawaban yang salah. ${ }^{19}$

Selain tingkat kesukaran, parameter lain yang penting dalam analisis butir soal adalah daya beda soal. Daya beda yang baik menunjukkan bahwa mahasiswa yang memiliki nilai tinggi (lulus) dapat memilih jawaban yang benar untuk soal tertentu dibandingkan mahasiswa yang memiliki nilai yang rendah. ${ }^{19}$ Daya beda soal merupakan indeks yang menunjukkan 
kemampuan dari pertanyaan untuk membedakan mahasiswa yang memiliki pengetahuan baik dan pengetahuan kuran $^{18}$ atau dalam penelitian ini mahasiswa yang lulus dengan yang tidak lulus dalam progress test tersebut. Oleh karena itu daya beda soal pada mahasiswa masa studi tahun pertama dan ke-2 tidak dapat dinilai karena tidak ada mahasiswa yang lulus sehingga tidak didapati kelompok mahasiswa pengetahuan baik yang akan dibandingkan dengan kelompok mahasiswa pengetahuan kurang yang pada penelitian ini adalah sebanyak $100 \%$. Daya beda soal pada mahasiswa angkatan tahun ke-3 mayoritas berada pada level buruk oleh karena pilihan-pilihan jawaban dalam paket soal tersebut kurang dapat dibedakan bila dibandingkan antara mahasiswa kelompok nilai tinggi (yang lulus) dengan kelompok mahasiswa nilai rendah (yang tidak lulus). Dalam penelitian yang dilakukan oleh Mirfat ${ }^{4}$ ditemukan bahwa pada analisis butir soal ditemukan bahwa tingkat kesukaran soal mayoritas berada pada level sedang (70\%), sedangkan daya beda soal mayoritas berada pada level buruk (55\%).

\section{Analisis Hasil Progress Test, Tingkat Kesukaran Soal, Serta Kategori Soal (Kedokteran Dasar dan Kedokteran Klinis) Dihubungkan Dengan Tahun Angkatan Belajar}

Tabel 4 berikut menunjukkan tingkat kesukaran soal berdasarkan kategori soal berdasarkan tahap ilmu kedokteran yaitu dasar dan klinis. Soal dengan kategori ilmu kedokteran dasar berjumlah 35 butir, dan kategori ilmu kedokteran klinis berjumlah 85 butir dengan total soal sebanyak 120 butir. Pada mahasiswa angkatan masa studi tahun ke-1 dan tahun ke-2, seluruh butir soal baik kategori ilmu kedokteran dasar maupun klinis berdasarkan tingkat kesukarannya berada pada level sukar (100\%). Pada mahasiswa angkatan masa studi tahun ke-3, soal dengan kategori ilmu kedokteran dasar dan klinis masing-masing berada pada level sedang yaitu sebesar 60\% dan 61.2\%. Demikian pula pada mahasiswa angkatan masa studi tahun ke-4, soal pada kategori ilmu kedokteran dasar dan klinis berada pada level sedang yaitu sebesar $57.2 \%$ dan $57.6 \%$.

Tabel 4. Tabulasi Silang Tingkat Kesukaran Soal dengan Kategori Soal Progress Test Mahasiswa FK UHN Semester Genap T.A 2018/2019

\begin{tabular}{clcccccc}
\multirow{2}{*}{$\begin{array}{c}\text { Angkatan Masa } \\
\text { Studi }\end{array}$} & Kategori Soal & \multicolumn{6}{c}{ Tingkat Kesukaran Soal } \\
\cline { 3 - 8 } & & \multicolumn{2}{c}{ Mudah } & \multicolumn{2}{c}{ Sedang } & \multicolumn{2}{c}{ Sukar } \\
\cline { 2 - 8 } Tahun ke-1 & Dasar & 0 & 0 & 0 & 0 & 35 & 100 \\
& Klinis & 0 & 0 & 0 & 0 & 85 & 100 \\
\multirow{3}{*}{ Tahun ke-2 } & Dasar & 0 & 0 & 0 & 0 & 35 & 100 \\
& Klinis & 0 & 0 & 0 & 0 & 85 & 100 \\
\multirow{2}{*}{ Tahun ke-3 } & Dasar & 1 & 2.8 & 21 & 60 & 13 & 37.2 \\
& Klinis & 5 & 5.9 & 52 & 61.2 & 28 & 32.9 \\
\multirow{2}{*}{ Tahun ke-4 } & Dasar & 3 & 8.6 & 20 & 57.2 & 12 & 34.2 \\
& Klinis & 13 & 15.3 & 49 & 57.6 & 23 & 27.1 \\
\hline
\end{tabular}

Pada penelitian ini, kategori soal dibagi atas ilmu kedokteran dasar dan klinis. Namun bagi mahasiswa angkatan masa studi tahun ke-1 dan ke-2, kedua kategori soal ini berada pada level sukar (100\%). Hal yang berbeda ditunjukkan oleh mahasiswa angkatan masa studi tahun ke-3 dan ke-4, untuk tingkat kesukaran, persentase jumlah soal yang dianggap mudah lebih banyak pada kategori ilmu kedokteran klinis dibandingkan ilmu kedokteran dasar (masing-masing 5.9\% terhadap 2.8\% dan 15.3\% dan $8.6 \%$ ). Persentase jumlah soal dengan tingkat kesukaran sedang tidak berbeda signifikan antara kedua kategori soal tersebut (masing-masing 61.2\% terhadap $60 \%$ dan $57.6 \%$ terhadap 57.2\%). Namun 
soal dengan tingkat kesukaran sukar, lebih banyak dari kategori ilmu kedokteran dasar (masing-masing $32.9 \%$ terhadap $37.2 \%$ dan $27.1 \%$ terhadap $34.2 \%$ ). Hal ini disebabkan mahasiswa pada tingkat ini sudah lebih banyak memahami ilmu kedokteran klinis dibandingkan ilmu kedokteran dasar. Pada tahap ini, mahasiswa lebih banyak terpapar dengan masalah klinis dibandingkan dengan ilmu dasar yang lebih banyak dipelajari pada tahun pertama studinya. ${ }^{12}$

Tabel 5 menunjukkan daya beda soal untuk kategori soal berdasarkan tahap ilmu kedokteran yaitu dasar dan klinis pada tiap angkatan. Daya beda soal untuk mahasiswa angkatan masa studi tahun ke-1 dan ke-2 tidak dapat ditentukan karena tidak ada mahasiswa yang lulus pada kedua angkatan tersebut, sehingga daya beda yang dibandingkan pada mahasiswa kelompok tinggi (mahasiswa yang lulus) dan mahasiswa kelompok rendah (mahasiswa yang tidak lulus) tidak dapat dihitung. Pada mahasiswa angkatan masa studi tahun ke-3 dan ke-4, daya beda soal berada pada level jelek baik pada kategori ilmu kedokteran dasar dan klinis yaitu 68.6\% dan 44.7\% untuk angkatan 2016 dan $65.7 \%$ dan $61.2 \%$ untuk angkatan masa studi tahun ke-4.

Dalam analisis butir soal untuk daya beda menunjukkan hasil yang berbeda dibandingkan tingkat kesukaran soal untuk mahasiswa angkatan masa studi tahun ke-3 dan ke-4 (angkatan 2016 dan 2015). Mayoritas soal menunjukkan daya beda yang buruk baik untuk ilmu kedokteran dasar maupun klinis. Namun ilmu kedokteran dasar menunjukkan daya beda yang lebih buruk dibandingkan dengan ilmu kedokteran klinis. Mahasiswa lebih sulit membedakan jawaban soal-soal dari ilmu dasar yang kemungkinan sudah mulai dilupakan oleh karena pada tahun studi ini mereka lebih banyak terpapar dengan ilmu kedokteran klinis.

Tabel 5. Tabulasi Silang Daya Beda Soal dengan Kategori soal Progress Test Mahasiswa FK UHN Semester Genap T.A 2018/2019

\begin{tabular}{|c|c|c|c|c|c|c|c|c|c|}
\hline \multirow{3}{*}{$\begin{array}{l}\text { Angkatan } \\
\text { Masa Studi }\end{array}$} & \multirow{3}{*}{ Kategori Soal } & \multicolumn{8}{|c|}{ Daya Beda Soal } \\
\hline & & \multicolumn{2}{|c|}{ Jelek } & \multicolumn{2}{|c|}{ Lemah } & \multicolumn{2}{|c|}{ Sedang } & \multicolumn{2}{|c|}{ Baik } \\
\hline & & $\mathrm{n}$ & $\%$ & $\mathrm{n}$ & $\%$ & $\mathrm{n}$ & $\%$ & $\mathrm{n}$ & $\%$ \\
\hline \multirow{2}{*}{ Tahun ke-1 } & Dasar & - & - & - & - & - & - & - & - \\
\hline & Klinis & - & - & - & - & - & - & - & - \\
\hline \multirow{2}{*}{ Tahun ke-2 } & Dasar & - & - & - & - & - & - & - & - \\
\hline & Klinis & - & - & - & - & - & - & - & - \\
\hline \multirow{2}{*}{ Tahun ke-3 } & Dasar & 21 & 68.6 & 4 & 11.4 & 2 & 5.7 & 8 & 9.4 \\
\hline & Klinis & 38 & 44.7 & 12 & 14.1 & 7 & 8.2 & 28 & 32.9 \\
\hline \multirow{2}{*}{ Tahun ke-4 } & Dasar & 23 & 65.7 & 5 & 14.3 & 2 & 5.7 & 5 & 14.3 \\
\hline & Klinis & 52 & 61.2 & 11 & 12.9 & 13 & 15.3 & 9 & 10.6 \\
\hline
\end{tabular}

Penelitian ini memiliki keterbatasan dimana pada setiap angkatan tahun masa studi tidak ditentukan standar setting untuk masing-masing angkatan tersebut sehingga menggunakan satu standar kelulusan yaitu nilai $\geq 50$. Sebaiknya tiap angkatan mahasiswa memiliki standar pencapaian yang harus dilewati sehingga dapat dinilai hasilnya secara lebih objektif dan dapat dinilai progresifitasnya dari tiap tahun angkatan mahasiswa.

\section{KESIMPULAN}

Kesimpulan pada penelitian ini adalah bahwa progress test dapat digunakan sebagai alat untuk membantu melihat perkembangan kemampuan pengetahuan mahasiswa baik secara individu maupun angkatan. Nilai progress test yang dicapai mahasiswa semakin tinggi sesuai dengan lamanya masa studi mahasiswa. Analisis butir soal progress test yang dilakukan pada semester genap Tahun Ajaran 2018/2019 dengan 
peserta ujian mahasiswa angkatan masa studi tahun ke-1 hingga ke-4 (angkatan 2018, 2017, 2016, dan 2015) menunjukkan hasil tingkat kesukaran mayoritas pada level sedang, dan daya beda mayoritas pada level jelek baik untuk kategori soal ilmu kedokteran dasar dan ilmu kedokteran klinis. Berdasarkan analisis butir soal tersebut, perlu dilakukan evaluasi terhadap komponen soal berupa komposisi dan proporsi berdasarkan kemampuan dasar dan klinis, maupun terhadap proses dan metode pembelajaran yang diberikan kepada mahasiswa sesuai masa studinya.

\section{SARAN}

Saran dari penelitian ini adalah perlu dilakukan penelitian lebih lanjut untuk analisis butir soal dalam mengukur efisiensi distraktor pada soal sebagai alat untuk menunjukkan bahwa item soal dibuat dengan baik atau tidak untuk mencapai tujuan pembuatan soal tersebut. Selain itu perlu dilakukan penelitian untuk dapat menentukan standar kelulusan yang lazim dari masing-masing angkatan sesuai lama masa studi mahasiswa sehingga dapat dinilai secara objektif apakah mahasiswa pada masa studi tertentu telah mencapai target pembelajaran yang diharapkan sudah dikuasai oleh mahasiswa tersebut.

\section{DEKLARASI KEPENTINGAN}

Para penulis mendeklarasikan bahwa tidak terdapat konflik kepentingan apapun terkait studi pada naskah ini.

\section{KONTRIBUSI PENULIS}

Ade Pryta R. Simaremare - sebagai peneliti dan penulis naskah artikel penelitian.

\section{DAFTAR PUSTAKA}

1. Konsil Kedokteran Indonesia. Standar Kompetensi Dokter Indonesia. Jakarta; 2012.

2. Alwan I Al, Kushi A Al, Albanyan E, Zamakhshary M, Kadri HMF Al. The Progress Test as a Diagnostic Tool for a New PBL Curriculum. 2011: 1-10.

3. Vleuten C Van Der, Sluijsmans D. Competence Assessment as Learner Support in Education. 2017: 607-30.
4. Mirfat, Yuhernita. Pemanfaatan Progress Test Sebagai Tolak Ukur Keberhasilan Belajar Mahasiswa. J Pendidik Kedokt Indones. 2014; $3(3): 170-6$.

5. Wrigley W, Vleuten CPMVANDER, Freeman A, Muijtjens A. AMEE GUIDE A systemic framework for the progress test: Strengths, constraints and issues : AMEE Guide No . 71. 2012; 31(71): 683-97.

6. Vleuten C Van Der, Freeman A, Fernando C. Progress test utopia. 2018; 2-4.

7. Tomic ER, Martins MA, Lotufo PA, Benseñor IM. Progress Testing: Evaluation of Four Years of Application in the School of Medicine, University of Sao Paulo. 2005; 60(5): 389-96.

8. Presiden Republik Indonesia. Undang-Undang Republik Indonesia Nomor 20 Tahun 2013 Tentang Pendidikan Kedokteran. Presiden Republik Indonesia; 2013.

9. Fitri AD. Penerapan Problem Based Learning (PBL) dalam Kurikulum Berbasis Kompetensi. JMJ. 2016; 4(1): 95-100.

10. Gipps C V. Beyond Testing: Towards a Theory of Educational Assessment. Routledge; 2015.

11. Schuwirth LWT, Vleuten CPM Van Der. The use of progress testing. 2012; 24-30.

12. Williams RG, Klamen DL, White CB, Petrusa E, Fincher RE, Whitfield CF, et al. Tracking Development of Clinical Reasoning Ability Across Five Medical Schools Using a Progress Test. Acad Med. 2011; 86(9): 1148-54.

13. Chen Y, Henning M, Yielder J, Jones R, Wearn A, Weller J. Progress testing in the medical curriculum : students ' approaches to learning and perceived stress. BMC Med Educ. 2015; 1-8.

14. Tio RA, Schutte B, Meiboom AA, Greidanus J, Dubois EA, Bremers AJA. The progress test of medicine : the Dutch experience. Perspect Med Educ. 2016; 5: 51-5.

15. Karelia BN, Pillai Aj, Vegada BN. The Levels of Difficulty and Discrimination Indices and Relationship Between Them in FourResponse Type Multiple Choice Questions of Pharmacology Summative Tests of Year II M.B.B.S Students. le JSME. 2013; 7(2): 41-6. 
16. Suswati I. Analisis Validitas Materi Uji Multiple Choise Question dengan Learning Objectives Blok Endokrin. Saintika Med. 2011; 7(5): 14-9.

17. Aziza RN, Dzhalila D. Metode Kuantitatif dengan Pendekatan Klasik pada Aplikasi Analisis Butir Soal Sebagai Media Evaluasi Penentuan Soal yang Berkualitas. J Kaji Ilmu dan Teknol. 2018; 7(1): 15-23.
18. Afandi D, Budiningsih Y, Safitry O, Purwadianto A, Widjaja IR, Merlina D. Analisis Butir Uji , Reliabilitas, dan Validitas Tes Kaidah Dasar Bioetika. Maj Kedokt Indon. 2007: 205-10.

19. Hingorjo MR, Jaleel F. Analysis of One-Best MCQs : the Difficulty Index, Discrimination Index and Distractor Efficiency. J Pak Med Assoc. 2012; 62(2): 142-7. 